\title{
Comparative studies on in vitro free radical scavenging activity of aqueous, ethanol, ethylacetate and $n$-hexane extracts of leaves of Datura stramonium and Ocimum gratissimum
}

\author{
Chintem Williams D. G. ${ }^{*}$, Nzelibe Humphrey Chukwuemeka \\ Department of Biochemistry, Faculty of Science, Ahmadu Bello University, Zaria, Nigeria
}

\section{Email address:}

williamschintemdg@gmail.com (Chintem. W. D. G.), Zeechuks6@yahoo.com (N. H. Chukwuemeka)

\section{To cite this article:}

Chintem Williams D. G., Nzelibe Humphrey Chukwuemeka. Comparative Studies on in Vitro Free Radical Scavenging Activity of Aqueous, Ethanol, Ethylacetate and N-Hexane Extracts of Leaves of Datura stramonium and Ocimum gratissimum. Science Research. Vol. 3, No. 1, 2015, pp. 7-12. doi: 10.11648/j.sr.20150301.12

\begin{abstract}
The in vitro Free Radical Scavenging Activity of aqueous, ethanol, ethylacetate and $n$-hexane extracts of leaves of Datura stramonium and Ocimum gratissimum were investigated. Due to the fact that Free radicals are implicated in many diseases including diabetes mellitus, arthritis, cancer, ageing. etc. In the treatment of these diseases, antioxidant therapy has gained utmost importance. The phytochemical analysis was carried out by standard methods and the antioxidant activity of the various extracts were measured on the basis of the free radical scavenging activity of the extract on stable 1, 1-diphenyl 2-picrylhyorazyl (DPPH) at varying concentrations of the plant extracts $(20,40,60,80$ and $100 \mu \mathrm{g} / \mathrm{ml})$ and absorbance was measured at $517 \mathrm{~nm}$ using UV-Vis spectrophotometer. The results indicated that alkaloids, flavonoids, terpenoids, steroids and tannins were present in $D$. stramonium ethanol leaf extract while alkaloids, flavonoids, terpenoids and steroids were present $i n O$. gratissimum $\mathrm{n}$-Hexane leaf extract. The percentage inhibition of the solvent extracts at $100 \mu \mathrm{g} / \mathrm{ml}-$ aqueous $(30.77 \%)$, ethanol $(74.90 \%)$, ethylacetate $(49.94 \%)$ and n-hexane $(69.90 \%)$ for D. stramonium while for O. gratissimum - aqueous (45.84 \%), ethanol $(49.47 \%)$, ethylacetate $(63.94 \%)$ and n-hexane $(91.14 \%)$. Of all the extracts, $n$-hexane leave extract of $O$. gratissimum exhibited the highest free radical scavenging activity with $\mathrm{IC}_{50} 0.21 \mu \mathrm{g} / \mathrm{ml}$ compared to ethanol leave extracts of $D$. stramonium with $\mathrm{IC}_{50} 0.29 \mu \mathrm{g} / \mathrm{ml}$. This study revealed that $n$-hexane leaf extract of Ocimum gratissimum had a more potent antioxidant activity compared to the ethanol leaf extract of $D$. stramonium which had moderate antioxidant activity. Both plants extracts had no significant difference when compared with ascorbic acid standard $(0.19 \mu \mathrm{g} / \mathrm{ml})$ at $(\mathrm{P} \leq .05)$. The phytochemical profile of the plants might be responsible for their high antioxidant activity, thus justifying wide use of $O$. gratissimum in diet which could provide a source of high dietary antioxidants and $D$. stramonium in ethno-botanical applications.
\end{abstract}

Keywords: DPPH, Ascorbic Acid, Datura stramonium, Ocimum gratissimum, Antioxidant

\section{Introduction}

Free radicals play significant role in the pathogenesis of chronic diseases- cancer, rheumatoid-arthritis, diabetes and hypertension to mention a few $[1,2]$. This is because the major cellular component:- lipids, proteins, carbohydrate and nucleic acids are susceptible to damage by free radicals produced as byproducts of normal aerobic metabolism and metabolic reactions of drugs, toxins and alcohols. Natural antioxidants present in plants, confer protection against free radicals when consumed. Thus are important in maintaining good health $[3,4]$. Antioxidants are powerful metal chelators and operate cooperatively, employing a series of redox reactions to detoxify free radicals [5]. Research has strongly indicated that high intake of fruits, vegetables and whole grains which are rich in antioxidants are capable of lowering the risk of free radicals damaging ability [1].

Datura stramonium is a plant belonging to the family Solanaceae and commonly known as Jimson weed, "Haukata-yaro" in Hausa. Medically it has been used in the treatment of madness, epilepsy, burns and rheumatism [6]. D. stramonium contains hyoscine, as well as atropine, hyoscyamine, apohyoscine, and meteloidine, thus it is poisonous and hallucinogenic as well as acting as analgesic, 
and it is also used as mosquito repellant [7, 8). The anticholinergic property of the plant results in the inhibition of central and peripheral muscarinic neurotransmission [9]. Ocimum gratissimum is a vegetable plant belonging to the family of Lamiaceae and commonly known as Wild basil, "Efinrinajase" in Yoruba and "Nchuanwu" in Igbo [10, 11]. In Nigeria, the plant is used in folk medicine to treat different diseases such as upper respiratory tract infections, diarrhea, headache, skin diseases, pneumonia, cough, fever and conjunctivitis. Infusion of $O$. gratissimum leaves is used as pulmonary antiseptic, anti-tussivum and antispasmodial [12]. It is non-toxic and is used as a spice in soup commonly consumed in Nigeria and in West Africa. The objective of this work is to compare the antioxidant capacity of a well-known consumed spice $(O$. gratissimum) and a rarely consumed vegetable (D. stramonium) and to discuss the phytochemical profile of both plants.

\section{Material and Methods}

\subsection{Plant Materials/Extraction}

The plant leaves of $D$. stramonium were harvested from Gembu-Mambilla plateau Taraba State North Eastern Nigeria while O. gratissimum was harvested around Ahmadu Bello University Area A staff Quarters Zaria, Kaduna state Nigeria. The plants were identified with voucher number 108 and 1285 respectively. They were deposited at the Herbarium unit, Department of Biological Science, Ahmadu Bello University, Zaria. The leaves were washed, shade dried at room temperature and then milled into fine powder by BX Model electric mill (mesh size $0.5 \mathrm{~mm})$. A quantity $(50 \mathrm{~g})$ of the pulverized dried leave was suspended in $500 \mathrm{ml}$ of distilled water, ethanol, ethylacetate and n-hexane solvents for $48 \mathrm{hrs}$. respectively using cold maceration. The filtrates were concentrated using rotary evaporator at $45^{\circ} \mathrm{C}$ and the plant materials were tested for their phytochemical analysis and antioxidant activity.

\subsection{Phytochemical Analysis}

The qualitative and quantitave analysis of the following phytochemicals: alkaloids, tannins, flavonoids, terpenoids, anthraquinone, saponins, cardiac glycoside and sterols were carried out on the extracts using the standard procedure for identification of phytochemical constituents as described by Sofowora and Harbone [13, 14].

Test for Alkaloids.

Dragendoff's Test: Few drops of this reagent were added to $5 \mathrm{mls}$ of the extract. A rose-red precipitate indicates the presence of alkaloids [13].

Test for Tannins

Ferric Chloride Test: About $0.5 \mathrm{~g}$ of extract was dissolved in $10 \mathrm{ml}$ of distilled water, and then filtered. Few drops of ferric chloride solution were added to the filtrate. Formation of a blue-black precipitate indicates hydrolysable tannins and green precipitates indicate the presence of condensed tannin $[13,14]$.

\section{Test for Flavonoids}

About $0.5 \mathrm{~g}$ of extract was dissolved in $2 \mathrm{ml}$ of $50 \%$ methanol while heating. Metallic magnesium and four to five drops of concentrated HCI were added. A red or orange colour indicates the presence of flavonoids.

Test for Terpenoids

Using Salkowski's test, $5 \mathrm{ml}$ of the extract was mixed in $2 \mathrm{ml}$ of chloroform and $3 \mathrm{ml}$ of concentrated sulfuric acid was carefully added to form a layer. A reddish brown colouration of the interface formed will show a positive result for the presence of Terpenoids.

Test for Anthraquinone Derivatives

Test for Free Anthraquinone (Bornirager's Test): $2 \mathrm{~g}$ of the extract was shocked with $10 \mathrm{ml}$ of benzene and filtered. $5 \mathrm{ml}$ of $10 \%$ of ammonia solution was added to the filtrate and stirred. The production of a pink-red or violet colour indicates the presence of free Anthraquinone.

Test for Saponins

Frothing test: $2 \mathrm{~g}$ of the extract was dissolved in $10 \mathrm{ml}$ of distilled water. This was then shaken vigorously for 30 seconds and was allowed to stand for 30 minutes. A honey comb formed for more than $30 \mathrm{~min}$ indicates Saponin [13].

Test for Cardiac Glycosides.

About $2 \mathrm{ml}$ of the Extract was dissolved in glacial acetic acid containing traces of ferric chloride. The test tube was held at an angle of $45^{\circ} \mathrm{C}, 1 \mathrm{ml}$ of concentrated sulphuric acid was added down the side $[13,14]$

Test for sterols

About $2 \mathrm{ml}$ of acetic anhydride was added to $0.5 \mathrm{~g}$ of Ethanol extract of the sample with $2 \mathrm{ml}$ sulfuric acid. The colour change from violet to blue or green indicates the presence of sterol [13].

\subsection{DPPH Free Radical Scavenging Assay}

The antioxidant activity of the extracts was measured on the basis of the free radical scavenging activity of the stable 1 , 1-diphenyl 2-picrylhyrazyl (DPPH) according to the method described by Brand-Williams with slide modification of wavelength of $517 \mathrm{~nm}$ instead of $520 \mathrm{~nm}$ [15]. A solution of $0.1 \mathrm{mM}$ DPPH in methanol was prepared and $1.0 \mathrm{ml}$ was mixed with varying concentrations of the plant extract suspension $(20,40,60,80$ and $100 \mu \mathrm{g} / \mathrm{ml})$. A corresponding blank containing equal volume of $1 \mathrm{ml}$ methanol and $1 \mathrm{ml}$ DPPH solution was prepared used while the standard control L-Ascorbic acid $(20-100 \mu \mathrm{g} / \mathrm{ml})$ was used as reference standard. All the reaction mixtures were carried out in triplicates and the decrease in absorbance was measured at $517 \mathrm{~nm}$ after 30 minutes in dark, using UV-Vis spectrophotometer. The percentage inhibition and $\mathrm{IC}_{50}$ were calculated using the following formula.

$$
\text { DPPH \% Inhibition }=\frac{\left(A_{\mathrm{DPPH}}-\mathrm{A}_{\text {Sample }}\right)}{\mathrm{A}_{\mathrm{DPPH}}} \times \frac{100}{1}
$$

$\mathrm{A}_{\mathrm{DPPH}}$ is the absorbance of methanol solution of 2 , 32-diphenyl-1-picryl hydrazyl

A sample is the absorbance of sample. 


\section{Results and Discussion}

\subsection{The Qualitative Determination of Phytochemicals in Aqueous, Ethanol, Ethylacetate and $\mathrm{N}$-Hexane Extracts of D. Stramonium and O. Gratissimum}

The result in Table 1 shows the phytochemical profile of aqueous, ethanol, ethylacetate and n-hexane extracts of the two plants. D. stramonium indicates the presence of alkaloids, and tannins while only flavonoids were absent in the aqueous extract. Both Terpenoids and anthraquinones were absent in Ethylacetate extracts, however only Terpenoids were present in the n-hexane extract of $D$. stramonium. Cardiac glycoside and saponins were absent in all the extracts of $D$. stramonium. Also on the other hand O. gratissimum indicates the presence of alkaloid, flavonoids, terpenoids and sterol in all extracts while, Cardiac glycoside and anthraquinones were completely absent in all the solvent extracts. Saponins and Tannins were absent in aqueous extracts of $O$. gratissimum, but were present in ethylacetate extracts of $O$. gratissimum.

\subsection{Quantitative Phytochemical Composition of D. Stramonium and 0 . gratissimum Leaf Extract}

The result in Table 2, shows significantly high amounts of, terpenoids tannins, flavonoids and alkaloid ranging from 0.61-2.24 mg/g $(\mathrm{P}<.05)$ in D. stramonium in increasing order and also significantly amounts of flavonoids steroids and alkaloid were found ranging from $1.28-0.98 \mathrm{mg} / \mathrm{g}$ of $(\mathrm{P}<.05)$ in O. gratissimum. While there was low amount of saponins in both plants and there were variations in percentage composition of these compounds in the plants.

Table 1. Phytochemical profiling of D. stramonium and O. gratissimum extract in selected extraction solvents.

\begin{tabular}{|c|c|c|c|c|c|c|c|c|}
\hline \multirow[b]{2}{*}{ Phytochemical } & \multicolumn{4}{|c|}{ D. stramonium } & \multicolumn{4}{|c|}{ O. gratissimum } \\
\hline & Aqueous & Ethanol & Ethylacetate & n-Hexane & Aqueous & Ethanol & Ethylacetate & n-Hexane \\
\hline Alkaloid & + & + & + & - & + & + & + & + \\
\hline Tanins & + & + & + & - & - & - & + & - \\
\hline Flavonoids & - & + & + & - & + & + & + & + \\
\hline Terpenoids & + & + & - & + & + & + & + & + \\
\hline Anthraquinone & + & + & - & - & - & - & - & - \\
\hline Saponins & - & - & - & - & - & + & + & + \\
\hline Sterols & + & + & + & + & + & + & + & + \\
\hline
\end{tabular}

$+=$ Positive $;=$ Trace $;-=$ Negative

Table 2. Quantitative phytochemical composition of D. stramonium and $O$. gratissimum leaf Extract.

\begin{tabular}{lll}
\hline Phytochemical & DSEE & OGnHE \\
\hline Alkaloid $(\mathrm{mg} / \mathrm{g})$ & $2.24 \pm 0.22 \mathrm{a}$ & $1.28 \pm 0.15 \mathrm{a}$ \\
Saponin $(\mathrm{mg} / \mathrm{g})$ & $0.14 \pm 0.00 \mathrm{~b}$ & $0.22 \pm 0.10 \mathrm{a}$ \\
Flavonoids $(\mathrm{mg} / \mathrm{g})$ & $0.78 \pm 0.04 \mathrm{a}$ & $0.98 \pm 0.34 \mathrm{a}$ \\
Sterols $(\mathrm{mg} / \mathrm{g})$ & $0.02 \pm 0.00 \mathrm{~b}$ & $1.14 \pm 0.42 \mathrm{a}$ \\
Tannins $(\mathrm{mg} / \mathrm{g})$ & $0.73 \pm 0.10 \mathrm{a}$ & $0.18 \pm 0.01 \mathrm{~b}$ \\
Terpenoids $(\mathrm{mg} / \mathrm{g})$ & $0.61 \pm 0.01 \mathrm{a}$ & $0.23 \pm 0.04 \mathrm{~b}$ \\
\hline
\end{tabular}

Mean $\pm \mathrm{SD}, \mathrm{n}=5$. $(\mathrm{P} \leq .05)$. DSEE $=$ Datura stramonium Ethanol Extract, $\mathrm{OGnHE}=$ Ocimum gratissimum n-Hexane extract.

\subsection{Percentage (\%) Inhibition of D. Stramonium and $O$. Gratissimum in Aqueous, Ethanol, Ethylacetate and n-Hexane Leaf extracts on DPPH Free Radical Scavenger}

Tables 3 and 4 shows percentage inhibition of the extract on DPPH Free radical scavenging activity which were found to be low for aqueous and ethylacetate extracts, while on the other hand high inhibition was observed in ethanol and $n$-hexane extracts at high concentration $(100 \mu \mathrm{g} / \mathrm{ml})$ in a dose response dependent pattern $(74.90 \pm 12.39$ and $69.90 \pm 2.39) \%$ respectively. At $60 \mathrm{ug} / \mathrm{ml}$ ethanol extract recorded a high percentage inhibition $(81.28 \pm 2.00 \%)$.

Table 3. Percentage (\%) Inhibition of D. stramonium in aqueous, Ethanol, ethylacetate and $n$-hexane leaf extracts on DPPH radical scavenger.

\begin{tabular}{|c|c|c|c|c|c|}
\hline \multirow{2}{*}{$\operatorname{Extract}(\mu \mathrm{g} / \mathrm{ml})$} & \multicolumn{4}{|c|}{ Percentage (\%) Inhibition } & \multirow[b]{2}{*}{ Ascorbic acid } \\
\hline & Aqueous & Ethanol & Ethylacetate & Hexane & \\
\hline 20 & $30.45 \pm 4.34^{\mathrm{a}}$ & $60.09 \pm 1.47^{\mathrm{a}}$ & $35.26 \pm 1.47^{\mathrm{b}}$ & $60.51 \pm 2.00^{\mathrm{a}}$ & $79.82 \pm 0.22^{\mathrm{a}}$ \\
\hline 40 & $36.54 \pm 2.54^{\mathrm{b}}$ & $65.30 \pm 1.47^{\mathrm{b}}$ & $28.85 \pm 3.47^{\mathrm{a}}$ & $65.85 \pm 0.00^{\mathrm{b}}$ & $89.43 \pm 0.52^{b}$ \\
\hline 60 & $40.39 \pm 0.96^{\mathrm{b}}$ & $81.28 \pm 2.00^{\mathrm{d}}$ & $43.91 \pm 1.40^{\mathrm{c}}$ & $68.00 \pm 5.35^{\mathrm{e}}$ & $89.13 \pm 0.75^{b}$ \\
\hline 80 & $31.41 \pm 1.11^{\mathrm{a}}$ & $67.35 \pm 10.03^{b}$ & $45.83 \pm 0.85^{\mathrm{c}}$ & $67.35 \pm 5.03^{\mathrm{c}}$ & $91.34 \pm 0.18^{\mathrm{c}}$ \\
\hline 100 & $30.77 \pm 0.00^{\mathrm{a}}$ & $74.90 \pm 12.39^{\mathrm{e}}$ & $49.94 \pm 1.16^{\mathrm{d}}$ & $69.90 \pm 2.39^{c}$ & $92.42 \pm 0.16^{\mathrm{c}}$ \\
\hline
\end{tabular}

Values represent Mean $\pm \mathrm{SD}(\mathrm{n}=5$ values $)$ in the same column with different superscript differs significantly $(\mathrm{P} \leq .05)$.

On the other hand the DPPH free radical scavenging activities of all the extracts of $O$. gratissimum increased markedly with the concentrations. In all extracts of aqueous, ethanol, ethylacetate and n-hexane presented in this study, $O$. gratissimum showed better inhibition than $D$. stramonium extracts. The Percentage (\%) Inhibition of the free radical at
$100 \mu \mathrm{g} / \mathrm{ml}$ for aqueous, ethanol, ethylacetate and hexane extracts from the dry leaf samples of $O$. gratissimum showed activity ranging between $45.84 \pm 0.16,49.47 \pm 0.96,63.84 \pm 2.00$ and $91.14 \pm 0.16 \%$ percent inhibition. The highest percentage inhibition was recorded in $n$-Hexane crude extract while the least inhibition pattern observed in aqueous extract. 
Table 4. Percentage (\%) Inhibition of O. gratissimum in aqueous, ethanol, ethylacetate and $n$-hexane leaf extracts on DPPH radical scavenger.

\begin{tabular}{llllll}
\hline \multirow{2}{*}{ Extract $(\boldsymbol{\mu g} / \mathbf{m l})$} & \multicolumn{5}{c}{ Percentage (\%) Inhibition } \\
\cline { 2 - 6 } & Aqueous & Ethanol & Ethylacetate & Hexane & Ascorbic acid \\
\hline 20 & $20.72 \pm 0.16^{\mathrm{a}}$ & $35.83 \pm 0.56^{\mathrm{a}}$ & $41.26 \pm 1.47^{\mathrm{a}}$ & $84.82 \pm 0.16^{\mathrm{a}}$ & $79.82 \pm 0.22^{\mathrm{a}}$ \\
40 & $28.42 \pm 0.16^{\mathrm{b}}$ & $36.54 \pm 1.67^{\mathrm{a}}$ & $48.85 \pm 6.00^{\mathrm{b}}$ & $87.43 \pm 0.15^{\mathrm{b}}$ & $89.43 \pm 0.52^{\mathrm{b}}$ \\
60 & $43.90 \pm 0.21^{\mathrm{bc}}$ & $34.62 \pm 2.54^{\mathrm{a}}$ & $58.91 \pm 2.42^{\mathrm{c}}$ & $89.13 \pm 0.05^{\mathrm{cd}}$ & $89.13 \pm 0.75^{\mathrm{b}}$ \\
80 & $45.48 \pm 0.16^{\mathrm{c}}$ & $45.83 \pm 2.00^{\mathrm{b}}$ & $60.83 \pm 1.47^{\mathrm{c}}$ & $90.43 \pm 0.05^{\mathrm{d}}$ & $91.34 \pm 0.18^{\mathrm{bc}}$ \\
100 & $45.84 \pm 0.16^{\mathrm{c}}$ & $49.47 \pm 0.96^{\mathrm{c}}$ & $63.94 \pm 2.00^{\mathrm{d}}$ & $91.14 \pm 0.16^{\mathrm{d}}$ & $92.42 \pm 0.16^{\mathrm{c}}$ \\
\hline
\end{tabular}

Values represent Mean $\pm \mathrm{SD}(\mathrm{n}=5$. Value(s) in the same column with different superscript differs significantly $(\mathrm{P} \leq .05)$.

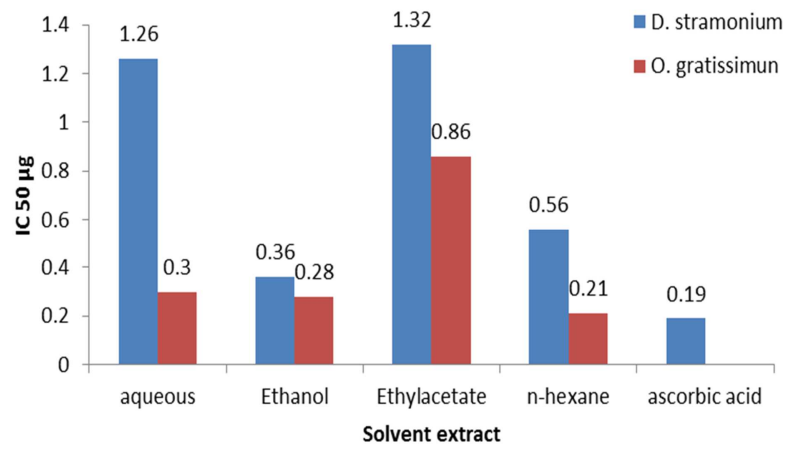

Figure 1. Comparative Median Inhibitory Concentration (IC50) values of the different solvent of D. stramonium and $O$. gratissimum leave extracts.

\subsection{Comparative Median Inhibitory Concentration $\left(I C_{50}\right)$ of the Different Solvents of D. stramonium and $O$. gratissimum Leave Extracts}

The comparative Median inhibitory concentration of different solvents of $D$. stramonium and $O$. gratissimum leave extracts against DPPH free radical scavenging activity indicating $\mathrm{IC}_{50}$ values of the different solvent extract which is the concentration of the sample required to scavenge $50 \%$ of the free radicals present in the system (Figure 1). Therefore IC50 value is inversely related to the antioxidant activity of the extracts. For $O$. gratissimum, it was observed that n-hexane extracts had the highest antioxidant potential $\left(\mathrm{IC}_{50}=0.21 \mu \mathrm{g}\right)$ followed by ethanol, aqueous and ethylacetate extracts respectively when compared to the reference standard ascorbic acid $\left(\mathrm{IC}_{50}=0.19 \mu \mathrm{g}\right)$. While in D. stramonium, the Lowest $\mathrm{IC}_{50}$ value was found in ethanol extract as $\left(\mathrm{IC}_{50}=0.36 \mu \mathrm{g}\right)$ compared to ascorbic acid.

\section{Discussion}

The administration of exogenous antioxidants seems to be salutary. Nowadays, a great deal of effort being expended to find effective antioxidants for the treatment or prevention of free radical-mediated deleterious effects [16, 18]. The medicinal effect of a number of plants extracts in the management and treatment of diseases linked with oxidative stress is attributed to their phytochemical constituent. These phytochemical substances which include: alkaloids, tannins, flavonoids, phenols and minerals have been ascribed biological and medicinal values such as: anti-diabetic, anti-atherosclerotic, anti-inflammatory, anti-carcinogenic and anti-microbial properties $[17,18]$. Phytochemical constituents in the plant samples are known to be biologically active compounds and they are accountable for diverse activities such as antioxidant, antimicrobial and anticancer (18). All secondary metabolites display antioxidant and antimicrobial properties through different biological mechanisms. The phytochemical screening of hexane, ethyl acetate, ethanol and aqueous crude extracts of $D$. stramonium and $O$. gratissimum used in this study revealed that the crude extracts contain alkaloids, flavonoids, terpenoids, steroids and tannins (Table 1) which co-related to the work of Phytochemical was in agreement with the previous claims $(17,18)$. From the results obtained it is evident that all the solvent extracts from $D$. stramonium and $O$. gratissimum leave possess free radical scavenging potential found to be in the decreasing order of $n$-hexane extract $>$ ethanol extract $>$ ethyl acetate extract $>$ aqueous extract. The antioxidant activity of the solvent extracts from $O$. gratissimum leaves was higher compared to those of $D$. stramonium leaf extracts. The differences in the percentage inhibition obtained from D. stramonium and O. gratissimum crude extracts might probably be due to the toxic nature and presence of anti-nutrient content of $D$. stramonium which may be capable of lowering the antioxidant potential of all solvent extracts compared to $O$. gratissimum. The n-hexane extract of O. gratissimum displayed maximum inhibition (91.14 $\pm 0.16 \%)$ at the highest concentration $(100 \mu \mathrm{g} / \mathrm{ml})$ was higher than $(74.90+12.31 \%)$ of ethanol leaf extract of $D$. stramonium in the present study due to high concentration of flavonoid, terpenoids and tannins which may be accountable for the high antioxidant activity $[21,22]$. The principle that accounts for the antioxidant activity is the DPPH interaction to produce oxidative free radicals while the role of the plant extract is the oxidants reaction with the stable free radical, during the free radical reaction, DPPH (1, 1-diphenyl-2-picrylhydrazyl) is converted into 1, 1-dipheny 2-b-picrylhydrazine with colour change and rate of colour change gradually decreases to indicate the scavenging potentials of the extract antioxidant property. The ethanol and n-hexane extracts of D. stramonium and $O$. gratissimum contain flavonoids, terpenoids alkaloid and tannins. The phytochemical constituents such as flavonoid, phenols, tannins, saponins and sterols are found in D. metel is known for their antioxidant potential [22, 23]. All these bioactive compounds were able to discolour DPPH solution by their hydrogen donating ability [24, 25, 26 and 27]. While $n$-hexane extract of $O$. gratissimum is rich in flavonoids, Terpenoids, Sterol and Alkaloid [26]. Based on the results of this study it can 
be considered that $O$. gratissimum $n$-Hexane extract and $D$. stramonium ethanol extract are good antioxidant and hydrogen donors to DPPH free radical. Assessment of DPPH scavenging activity found from this study is slightly higher than the values those found by James et al [18, 29] studied the DPPH scavenging activity in Vertex duniana and significantly higher the works of Olabinri et al [30]. This may be attributed to the presence Alkaloid, Flavonoids, Terpenoids, Saponins and Sterols that exhibit strong antioxidant properties [16]. Moreover, [32] reported that antioxidant activity of plant extracts containing polyphenolic compounds have capacity to be donate hydrogen atoms or electrons and to capture the free radicals. The radical scavenging potential of the reference antioxidant standard (Ascorbic acid) was higher than that of the extract. However, the leafy vegetables could serve as good source of food and medicine to treat oxidative stress in diseases related to generation of free radicals.

\section{Conclusion}

This study revealed that $O$. gratissimum $n$-hexane crude leaf extract showed the higher antioxidant activity than ethanol crude leaf extract from $D$. stramonium. The phytochemical screening indicated that the antioxidant activities was due to the presence of alkaloids, flavonoids, terpenoids, steroids and saponins in $O$. gratissimum $n$-hexane extract while alkaloids, flavonoids terpenoids, steroids, anthraquinone and tannins in D. stramonium ethanol extract served as a potential sources of new antioxidant which could be exploited for drug development. The leaves of $O$. gratissimum which are widely used as spice in soup especially in African countries could be considered as a good source of antioxidant as observed in DPPH scavenging assay compared to D. stramonium though toxic when consumed in high dose but low dose has shown to be a good antioxidant. Thus the use of $O$. gratissimum leaf extract as a source of dietary antioxidant.

\section{Acknowledgements}

The Authors acknowledge all the contributions and assistance of the Technical Staff, the Head of Department and Dr. D.B. James all of the Department of biochemistry A.B.U Zaria for technical support and the entire family of Genesis K. Chintem for financial assistant to complete this research work, thank you.

\section{References}

[1] N. Ara, M. Rashid, M.S. Amrad, "Comparison of Maringa oleifera Leaves Extract with Atenolol on Serum triglyceride, Serum Cholesterol, Blood glucose, heart weight, body weight in Adrenaline Induced Rats," Saudi J. Biol Sci. 2008;15:253-258.

[2] R. Tsao, "Chemistry and Biochemistry of Dietary Polyphenols." Nutrients. 2010:(2)1231-1246
[3] O. Blokhina, E. Virolainen, K. Fagerstedt, "Antioxidants, oxidative damage and oxygen deprivation stress", a review. Annals of Botany. 2003;91(0):179-194.

[4] L. Pari, M. Karamaæ, A. Kosiñska, A. Rybarczyk, R. Amarowicz, "Antioxidant activity of the crude extracts of drumstick tree (Moringa oleifera Lann.) and sweet Broomweed (Scoparia dulcis I.) Leaves." Pol. J. Food Nutr. Sci. 2007;57:203-208.

[5] E. Middleton, C. Kandaaswami, T. C. Theoharides, The Effects of Plant Flavonoids on Mammalian Cells: Implications for Inflammation, Heart Disease, and Cancer. Pharm Rev. 2000;52:673-751.

[6] S. Swathi, G. Murugananthan, SK. Ghosh, AS. Pradeep, Larvicidal and repellent activities of ethanolic extract of Datura stramonium leaves against Mosquitoes. Int J. Pharm Phytochem Res. 2012;41:25-27.

[7] J. A. Duke, and Ayensu, ES. Medicinal plants of China, Algonac Reference Publications. 1985;2: 544.

[8] S. Ivancheva, M. Nikolova, and R. Tsvetkova, Pharmacological activities and biologically active compounds of Bulgarian medicinal plants. In: Inperato, F, (ed). Phytochemisry: Advances in research. Kerala: Signpost, 2006; 87-103.

[9] A. Boumba, A. Mitselou, and T. Vougiouklakis, Fatal poisoning from ingestion of Datura stramonium seeds. Veterinary Human Toxicololgy, 2005; 46:81-82.

[10] M. Burkill, The useful plants of Tropical Africa. 2nd ed., Vol.1, Royal Botanic Gardens, Kew, London. 1985

[11] A. Mann, M. Gbate, A. Nda-Umar, Medicinal and Economic Plants of Nupeland. Jube-Evans Books and Publications, Bida, Nigeria. 2003

[12] M.B. Ngassoum, J. J. Jessia-Ngang, L. N. Tatsadjieu, L Jirovetz, G. Buchbauer and O. Adjoudji, Antimicrobial study of essential oils of Ocimum gratissimum leaves and Zanthoxylum xanthoxyloides fruits from Cameroon. Fitoterapia; 2003; 74(2) $284-287$.

[13] Sofowora EA. Phytochemical screening of Nigerian medicinal plants. Part II Lloydia, 1993;41(3):234-246

[14] Harborne JB. Phytochemical Methods, A guide to Modern Techniques of Plant analysis, second ed. Chapman and Hall, London 1998.

[15] Brand-williams W, Cuvelier ME and Berset C. Use of free radical method to evaluate antioxidant activity. Lebensmittel Wissenschaft and Technologie; 1995; 28(1):25-30.

[16] Hossain J., Urgessa K., Regassa F., Jemal A., Abajebel S. and Hussien N., (2011). Antihelmentic effects of the Essential oil extracts of selected Medicinal plants against Haemonchus contortus. Internat. J. Agric. Res., 6: 290-298.

[17] Afolabi CA., Ibukun EO, Afor, E., Obuotor, EM. and Farombi, EO. Phytochemical constituents and antioxidant activity of extract from the leaves of Ocimum gratissimum. Scientific Research and Essay, 2007; 2(5):163-166.

[18] Olofintoye, LK, Simon-Oke, IA and Omoregie, OB. Larvicidal Properties of Datura stramonium (Jimson Weed) and Nicotiana tabaccum (Tobacco) Extracts against the Larvae of (Anopheles and Culex) Mosquitoes. 2011;5(2): 337-344) 
12 Chintem Williams D. G. and Nzelibe Humphrey Chukwuemeka: Comparative Studies on in Vitro Free Radical Scavenging Activity of Aqueous, Ethanol, Ethylacetate and $n$-Hexane Extracts of Leaves of Datura stramonium and Ocimum gratissimum

[19] Olabinri BM., Fatunwase IO. and Olabinri PF. In vitro discovery of highly chelatable root extract of thorn apple (Datura stramonium). International Journal of Medicine and Medical Sciences 2014;6(2):75-79, DOI: 10.5897/IJMMS2013.0966

[20] Donatus EO, Ephraim CI. Isolation, characterization and antibacterial activity of alkaloid from Datura metel Linn leaves. African Journal of Pharmacy and Pharmacology. 2009; 3(5) $277-281$.

[21] E. Barile, G. Bonanomi, V. Antignani, B. Zolfaghari, S. S. Ebrahim, F. Scala, Phytochemical screening and antimicrobial assessment of Abutilon mauritianum, bacopa monifera and Datura stramonium. Phytochemistry. 2007; 68:596-603.

[22] G.A. Ayoola, H. A. B. Coker, S. A. Adesegun, A. A. Adepoju-Bello, K. Obaweya, E. C. Ezennia, Phytochemical screening and antioxidant activities of some selected medicinal plants used for malaria therapy in Southwestern Nigeria. Tropical Journal of Pharmaceutical Research 2008; 7(3)1019 1024.

[23] F. C. Akharaiyi, Antibacterial, phytochemical and antioxidant activities of Datura metel. Inl J Pharmacology Technology Research 2011;3(1)478-483.

[24] D. Sekar, K. Kolanjinathan, P. Saranraj, K. Gajendiran, Screening of Phyllanthus amarus, Acalypha indica and Datura metel for its antimicrobial activity against selected pathogens. Intl. J. of Pharmaceutical \& Biological Archives 2012;3(5)1231-1235.
[25] I. Koleva, A. B. Teris, P. H. Jozef, G. Aede, N. E. Lyuba, Screening of Plant Extracts for Antioxidant Activity: A Comparative Study on Three Testing Methods. Phytochem. Anal. 2002;13:8-17 DOI: 10.1002/pca.611

[26] K.S. Chukwuka, J.O. Ikheloa, I.O. Okonko, J.O. Moody, T.A. Mankinde. The antimicrobial activities of some medicinal plants on Escherichia colias an agent of diarrhoea in livestock. Advan. Appl. Sci.Res. 2011; 2: 37-48

[27] R. Khaled. Medicinal Plants with antioxidant Potential: A review Hygeia. Journal for drugs and medicines 6 (1) 106-110. 2014. DOI: 10.15254/H.J.D.Med.6.2014.127

[28] S., Sahoo, G., Ghosh, D., Das and S., Nayak. Phytochemical investigation and In vitro antioxidant activity of an indigenous medicinal plant Alpinia nigra BL Burtt. Asian Pacific journal of tropical biomedicine, 3, 871-876. 2013

[29] B. M., Olabinri, I. O. Fatunwase, and P. F. Olabinri. "In vitro discovery of highly chelatable root extract of thorn apple (Datura stramonium)." International Journal of Medicine and Medical Sciences 6.2 (2014): 75-79.

[30] Pellegrini, Nicoletta, Mauro Serafini, Barbara Colombi, Daniele Del Rio, Sara Salvatore, Marta Bianchi, and Furio Brighenti. "Total antioxidant capacity of plant foods, beverages and oils onsumed in Italy assessed by three different in vitro assays." The Journal of nutrition 133, no 9 (2003): 2812-2819. 